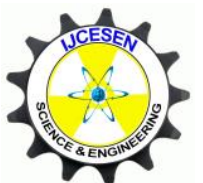

Copyright (C) IJCESEN
International Journal of Computational and

Experimental $\boldsymbol{S}$ cience and Engineering

(IJCESEN)

Vol. 4-No.3 (2018) pp. 15-19

http://dergipark.gov.tr/ijcesen

Research Article

\title{
Characterization of Hydroxyapatite Coating on Ti6Al4V by Sol-gel Method
}

\author{
Eyüp Can BİÇER ${ }^{1}$, Atilla EVCİN ${ }^{2}$, Gür Emre GÜRAKSIN ${ }^{1 *}$
}

${ }^{1}$ Afyon Kocatepe University, Engineering Faculty, Biomedical Engineering Department, Afyonkarahisar-Turkey ${ }^{2}$ Afyon Kocatepe University, Engineering Faculty, Material Science and Engineering Depart, Afyonkarahisar-Turkey

* Corresponding Author : emreguraksin@aku.edu.tr ORCID: 0000-0002-1935-278

\section{Article Info:}

DOI: $10.22399 /$ ijcesen. 379088

Received : 15 January 2018

Accepted : 7 August 2018

\section{Keywords :}

Biomaterials

Hydroxyapatite

Sol-Gel

Ti Implants

\begin{abstract}
:
Biomaterials are natural or synthetic materials that are used in human body and are materials to evaluate, treat, support or replace any tissue, organ, or function of the body. Due to its favorable biocompatibility and mechanical properties, HAcoated metal-based implants are used in the orthopedic surgery operations. For this purpose, sol-gel synthesized nano sized HA powders were produced. Ti6Al4V alloy was coated with hydroxyapatite (HA) by using the sol-gel method. Surface morphologies, thermal, mineralogical properties and bioactivity of the coatings were examined and the characterization of the coatings was performed by using DTA-TG, XRD, SEM, and EDX.
\end{abstract}

\section{Introduction}

Bone is a natural composite which mainly consists of an inorganic (Hydroxyapatite-HA) and an organic (collagen). Bones have different pore shapes according to their locations and functions throughout the body. The skeleton consists of two main structural types of bone as shown in Fig 1 . Compact (cortical) bone is dense with a low surface area. Spongy (trabecular or cancellous) bone has a lower density and larger surface area than compact bone. The mineral part of the bone is constituted by calcium phosphates, in the forms of crystallized HA and/or amorphous calcium phosphates (ACP), which contains various ions like $\mathrm{Na}+, \mathrm{Mg}^{2+}, \mathrm{K}^{+}$, $\mathrm{CO}_{3}^{2}-, \mathrm{Cl}^{-}$, and $\mathrm{F}^{-}[1,4]$.

HA is widely used as a substitute for bones and teeth owing to its excellent biocompatibility and its similar structure with the mineral part of the bone. However, its mechanical properties such as strength, hardness and toughness do not comply with mechanical properties of bone $[6,8]$.

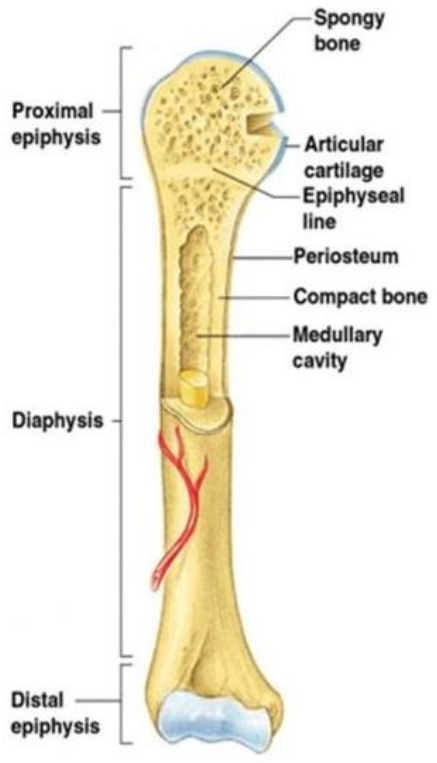

Figure 1 Bone structure [5].

Sol-gel process is an attractive alternative to other methods for synthesis of ceramics and glasses for many reasons: for example, low temperature synthesis, simple equipment to be used, thin film formability and so on [9-11]. 
Many researchers have used different methods for the fabrication of hydroxyapatite coatings such as plasma spray, HVOF, molecular beam epitaxy (MBE) vapor-liquid-solid mechanism (VLS) , solution-phase, shadow sputtering, and sol-gel methods [7].

In this work, we developed Hydroxyapatite nano particles and coating by sol-jel on Ti6Al4V metallic implant. Crystal structure, surface morphology, composition of samples was characterized by means of XRD, SEM, and EDX.

\section{Materials and Methods}

To synthesize powders chemically, Analytic grade $\mathrm{Ca}\left(\mathrm{NO}_{3}\right)_{2} \cdot 4 \mathrm{H}_{2} \mathrm{O},\left(\mathrm{NH}_{4}\right)_{2} \mathrm{HPO}_{4}, \mathrm{NH}_{4} \mathrm{OH}$ were used as precursors. All chemicals were purchased from Merck and used as received. Ti6Al4V (Grade 5) was used as metallic implant to coat. $1.00 \mathrm{M}$ stock solutions of calcium nitrate 4-hydrate and diammonium hydrogen phosphate were prepared using distilled water. A precipitate was formed by the drop-wise addition of the $\left(\mathrm{NH}_{4}\right)_{2} \mathrm{HPO}_{4}$ solution to the $\mathrm{Ca}\left(\mathrm{NO}_{3}\right)_{2}$ solution, with continuous stirring, to obtain a $\mathrm{Ca} / \mathrm{P}$ ratio of 1.67 in the mixed solution. The solution was brought to $\mathrm{pH} 11$ by addition of concentrated ammonium hydroxide solution (Fig 2). The obtained precipitation was HA. The precipitate was aged overnight at room temperature. The resulting powder was dried in an oven for $10 \mathrm{~h}$. Finally, the dried powder was calcined in an electrical furnace at $1000{ }^{\circ} \mathrm{C}$ for $2 \mathrm{~h}$ after heating at the rate of $5^{\circ} \mathrm{C} / \mathrm{min}$. in air.

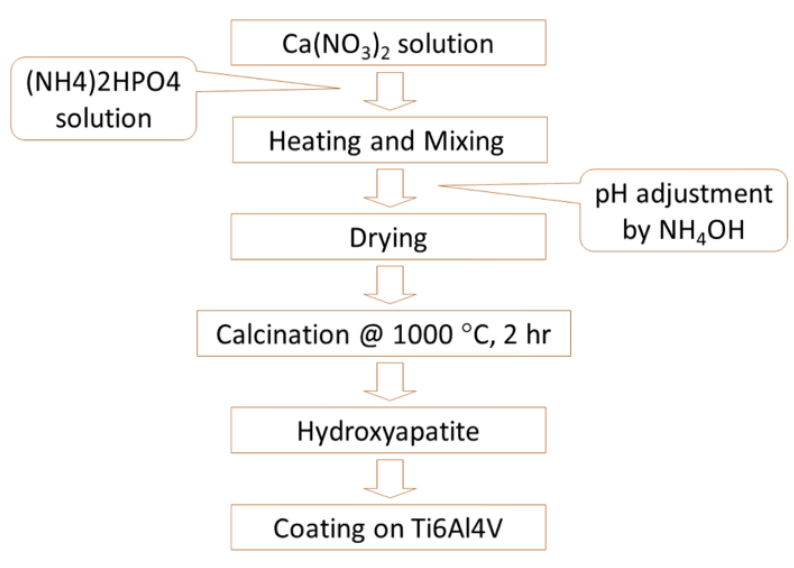

Figure 2 Experimental flow chart

This hydroxyapatite sol was deposited on a pre cleaned Ti6A14V metallic implant substrate by dip coating method (Fig 3). An average of four layers was required for each film with $100 \mu \mathrm{m}$ thickness.
Then these films were air dried after deposition and heated and dried at $100{ }^{\circ} \mathrm{C}$ in an oven for $15 \mathrm{~min}$. For hydroxyapatite phase formation, thin films were annealed at $500{ }^{\circ} \mathrm{C}$ for two hours at ambient conditions. Structural and thermal properties of calcined powders were characterized by XRD and DTA/TG respectively. Morphological and surface properties of annealed thin films were studied. In vitro bioactivity test of thin films were performed in stimulated body fluid (SBF) at $37^{\circ} \mathrm{C}$ under static condition for 1-21 days.
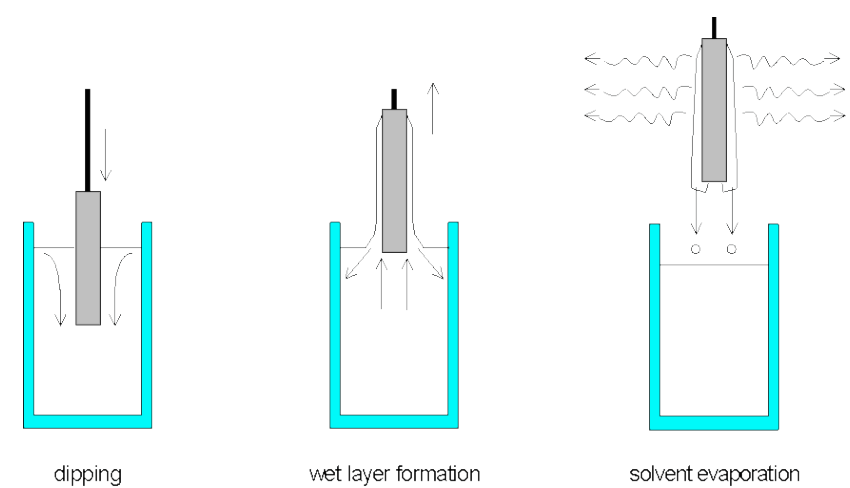

Figure 3. Dip coating process (http://www.solgel.com/articles/Nov00/mennig.htm)

\section{Results and Discussion}

The thermal properties of the HA powders were characterized by TG-DTA (Netzsch STA449F3) (Fig 4). There are one endothermic and two exothermic peak. An endothermic peak was found at $175{ }^{\circ} \mathrm{C}$, due to removal of water and organic elements from powder. Thermal decomposition of the powder began at $400{ }^{\circ} \mathrm{C}$. Second exothermic peak was observed at $800{ }^{\circ} \mathrm{C}$. After this reaction, the crystal structure of the system becomes stable. Total weight loss was $\% 11.44$.

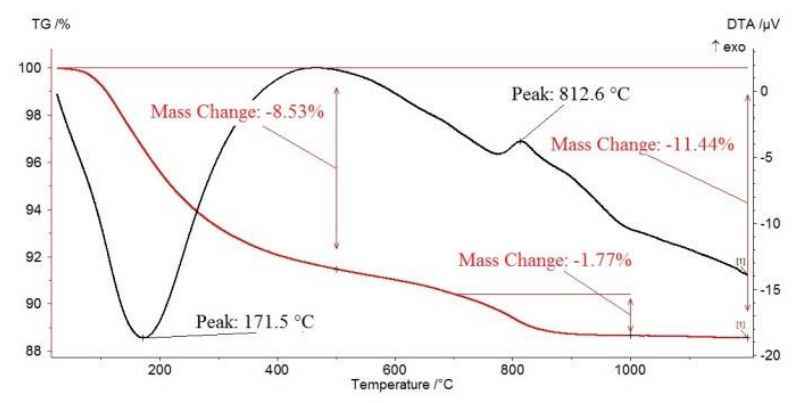

Figure 4. DTA/TG Diagram of Hydroxyapatite powders.

Crystal structures of the powders were characterized via powder X-ray diffraction (XRD, Bruker D 8 Advance) using $\mathrm{Cu}-\mathrm{K} \alpha \mathrm{X}$-rays of 
wavelength $=1: 5406 \AA$ and data were taken in the $2 \theta$ range of $20^{\circ}$ to $70^{\circ}$ with a step of $0.1972^{\circ}$. As can be seen in Fig. 4, all spectra showed the HA reflections.

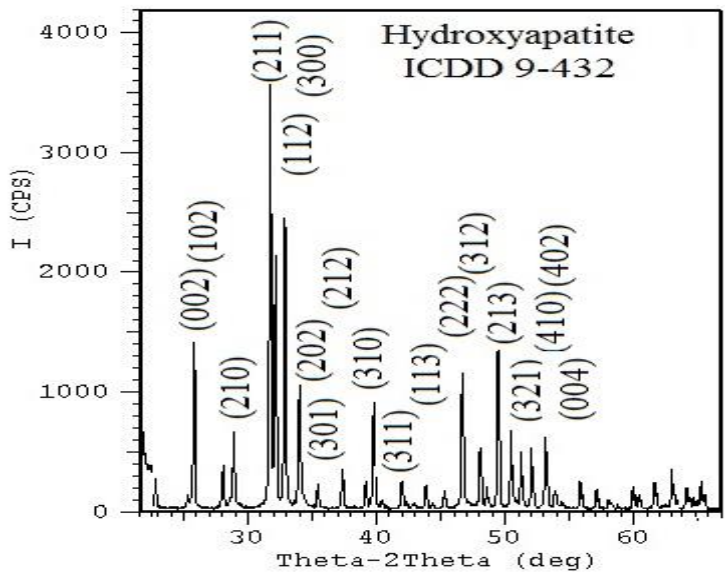

Figure 5. XRD patterns of HA powders

Thickness of coating layer and surface structure were obtained from the cross-sectional and surface images using a SEM-EDX (LEO $1430 \mathrm{VP}$ ). Fig 6 shows the morphology of HA powders. HA powders are approximatelly under $1 \mu \mathrm{m}$. Fig. 7 shows the surface morphology of the HA coating on Ti6Al4V. SEM image of coating surface is shown in Fig 7 to illustrate crack free, smooth and porous surface. SEM image of cross section is shown in Fig 8 to illustrate homogenous coating layer. Thickness of coating for HA was about 98 $\mu \mathrm{m}$.

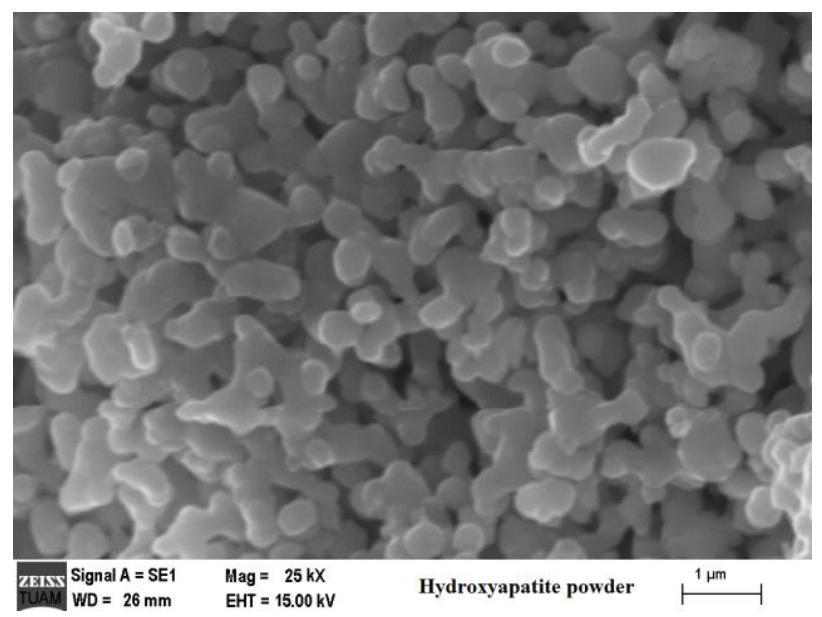

Figure 6. SEM image of HA powders

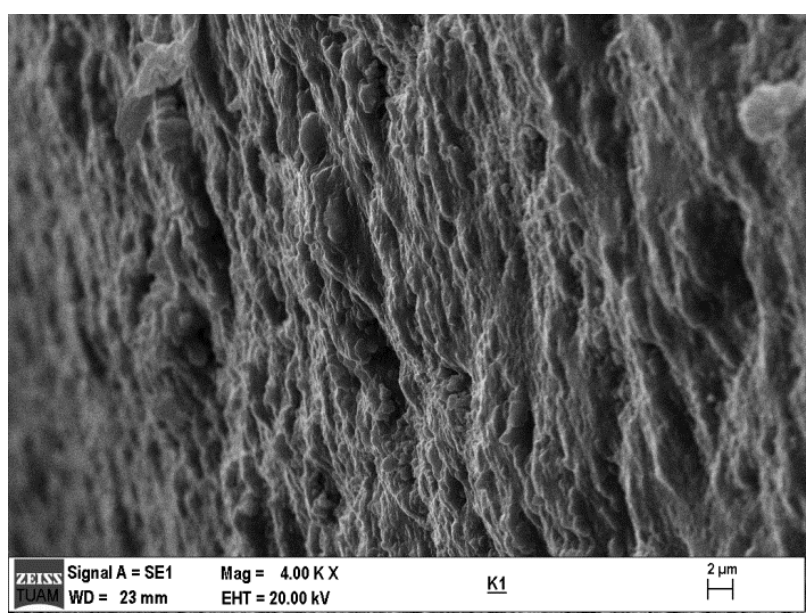

Figure 7. SEM image of HA coating surface.

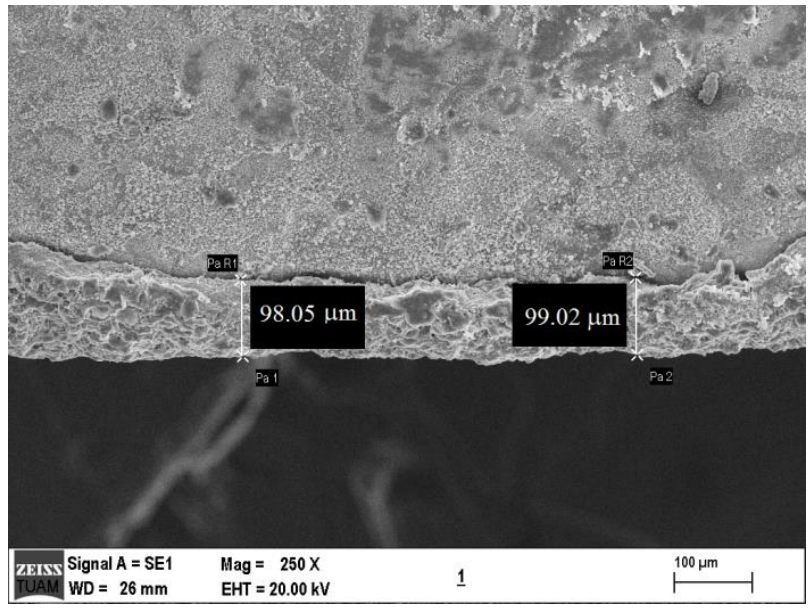

Figure 8. SEM image of HA coating cross section.

Table 1. SEM-EDX analysis of HA coating surface.

\begin{tabular}{|c|c|c|c|c|c|}
\hline Element & Series & Net & $\begin{array}{c}\text { Unn.C } \\
(\mathrm{wt} \%)\end{array}$ & $\begin{array}{c}\text { Nor. } \\
\mathrm{C} \\
(\mathrm{wt} \%)\end{array}$ & $\begin{array}{c}\text { Atom } \\
\mathrm{C} \\
(\mathrm{at} \%)\end{array}$ \\
\hline Carbon & $\mathrm{K}$ & 19643 & 11.77 & 9.75 & 19.24 \\
\hline Oxygen & $\mathrm{K}$ & 16174 & 41.41 & 34.28 & 50.79 \\
\hline Sodium & $\mathrm{K}$ & 3511 & 2.24 & 1.85 & 1.91 \\
\hline Aluminium & $\mathrm{K}$ & 6561 & 2.10 & 1.74 & 1.53 \\
\hline Silicon & $\mathrm{K}$ & 2129 & 0.58 & 0.48 & 0.41 \\
\hline Phosphorus & $\mathrm{K}$ & 3127 & 0.81 & 0.67 & 0.51 \\
\hline Chlorine & $\mathrm{K}$ & 6055 & 1.40 & 1.16 & 0.77 \\
\hline Calcium & $\mathrm{K}$ & 7716 & 1.69 & 1.40 & 0.83 \\
\hline Titanium & $\mathrm{K}$ & 159953 & 57.36 & 47.48 & 23.51 \\
\hline Iron & $\mathrm{K}$ & 2348 & 1.44 & 1.20 & 0.51 \\
\hline & & Total & 120.8 & 100.0 & 100.0 \\
\hline
\end{tabular}


As can be seen in Table $1, \mathrm{Ca} / \mathrm{P}$ atomic ratio is 1.63. Despite the well-recognized importance of single-phase HA, however, precisely stoichiometric $\mathrm{HA}$ (a $\mathrm{Ca} / \mathrm{P}$ ratio of exactly 1.67 ) is not always present.

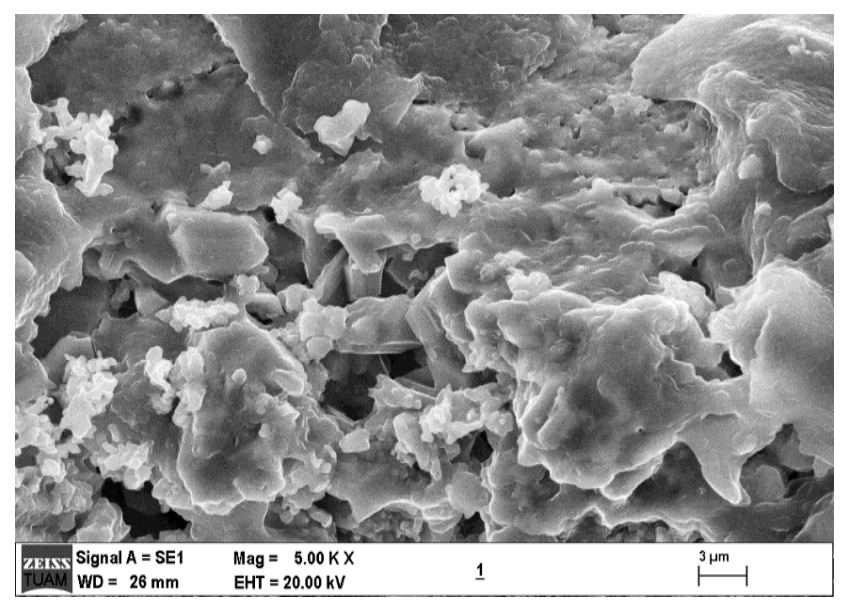

Figure 9. SEM images of surface (after SBF solution dipping)

In order to study the weight variety of HA coating in SBF, the dry weight of coating was measured before and after the incubation, and the percentage of weight increase (Wp) can be calculated according to the following equation (1):

$W_{p}=\frac{W_{b}-W_{a}}{W_{a}} x 100$

Where $\mathrm{W}_{\mathrm{b}}$ and $\mathrm{W}_{\mathrm{a}}$ represent the weight of sample after and before soaking in SBF, respectively. The mass change of samples before and after immersing in SBF for 1, 7, 14, and 21 days was measured by using an analytical balance (accuracy: $0.1 \mathrm{mg}$ ). All the samples were thoroughly rinsed with distilled water and dried at $65{ }^{\circ} \mathrm{C}$ before weighing. The bio resistivity of the specimens was assessed by SBF solution. This solution was prepared according to the protocol suggested by Kokubo et al. $[13,14]$ Then samples were weighed and characterized by SEM. As can be seen in Fig 9 new HA crystals occurred on surface. The results show that the amount of particles formed on the HA coated Ti6Al4V implant increased with the increasing of soaking time and the percentages of weight increase at immersing for $1,7,14$ and 21 days were $1,43 \%$, $3,18 \%, 10.40 \%$ and $17,42 \%$, respectively.

\section{Conclusion}

In this work, sol-gel synthesized (nano sized) hydroxyapatite (HA) powders were successfully produced and used for coating Ti6Al4V implant by using sol-gel method. Experiments we have demonstrated that HA can be coated on Ti6Al4V by sol-gel method at the low temperature.

Bioactivity results showed that HA coated Ti6Al4V implants are as equally successful as HA coated implants in achieving osseointegration. Finally it can be use in biomedical application as an implant. With the increase in soaking time, the amount of new hydroxyapatite seed formed on surface increased. This was confirmed by the weight assessment and SEM images.

XRD peaks of synthesized powders completely match with the standard HA peaks.

A dense and homogeneous surface layer is expected to contribute to high adhesion strength between the HA layer and the Ti6Al4V implant. The measured coating thickness of HA on Ti6Al4V is $98 \mu \mathrm{m}$.

Coating surface is homogeneous and smooth.

\section{Acknowledgement}

This study has been performed within project of 15.FEN.BIL.24 under the support of Afyon Kocatepe University Scientific Research Projects Coordination Unit.

This paper presented in " 4 rd International Conference on Computational and Experimental Science and Engineering (ICCESEN-2017)"

\section{References}

[1] Sam Zhang, Hydroxyapatite Coatings for Biomedical Applications, CRC Press, 2013, NewYork

[2] Andreas " Ochsner and Waqar Ahmed, Biomechanics of Hard Tissues, WILEY-VCH Verlag GmbH \& Co. KGaA, 2010, Weinheim

[3] F. C. M. Driessens, M. G. Boltong I. Khaïroun, E. A. P. De Maeyer, M. P. Ginebra, R. Wenz, J. A. Planell, R. M. H. Verbeeck, Applied Aspects of Calcium Phosphate Bone Cement Application, Biomaterials Engineering and Devices: Human Applications pp 253-260 doi.org/10.1007/978-159259-197-8_15

[4] Maria Vallet-Regi, Jose Maria Gonzalez-Calbet, Calcium phosphates as substitution of bone tissues,

Progress in Solid State Chemistry 32 (2004) 131 doi:10.1016/j.progsolidstchem.2004.07.001

[5] http://hagans.biz/39567_a_diagram_of_a_long_bone/ 2018/08

[6] Joon Park, Biomaterials An Introduction, Springer, 2007, Iowa

[7] O. Sahin, S. Uzunoglu And E. Sahin, Influence Of Pd Addition Of Cocrmo Biomedical Alloys On The Microhardness Behaviour, ACTA PHYSICA 
POLONICA A, Vol.128 (2015) B-145 DOI: 10.12693/APhysPolA.128.B-145

[8] G. Celebi Efe, M. İpek, C. Bindal and S. Zeytin, Pack Siliconizing of Ti6Al4V Alloy, ACTA PHYSICA POLONICA A, Vol 132 (2017) 760 DOI: 10.12693/APhysPolA.132.760

[9] A. Evcin, E. Arl1, Z. Baz, R. Esen, E.G. Sever, Characterization of $\mathrm{Ag}-\mathrm{TiO} 2$ Powders Prepared by Sol-Gel Process, ACTA PHYSICA POLONICA A, $\begin{array}{lllll}\text { Vol } & 132 & \text { (2017) } & 608 & \text { DOI: }\end{array}$ 10.12693/APhysPolA.132.608

[10] N. Çiçek Bezir, A. Evcin, R. Kayali, M.K. Özen, K. Esen, Comparison of Five-Layered $\mathrm{ZrO} 2$ and Single-Layered $\mathrm{Ce}, \mathrm{Eu}$, and Dy-Doped $\mathrm{ZrO} 2$ Thin Films Prepared by Sol-Gel Spin Coating Method, ACTA PHYSICA POLONICA A, Vol 132 (2017) 612 DOI: 10.12693/APhysPolA.132.612

[11] N. Çiçek Bezir, A. Evcin, R. Kayali, M.K. Özen, G. Balyaci, Comparison of Pure and Doped TiO2 Thin Films Prepared by Sol-Gel Spin-Coating Method, ACTA PHYSICA POLONICA A, Vol $132 \quad$ (2017) 620 DOI: 10.12693/APhysPolA.132.620

[12] Haibo Wang, Jong-Kook Lee, Amr Moursi, John J. Lannutti, $\mathrm{Ca} / \mathrm{P}$ ratio effects on the degradation of hydroxyapatite in vitro, Journal of Biomedical Materials Research Part A, Volume 67A, Issue 2, 1 November 2003, Pages 599-608 DOI: 10.1002/jbm.a. 10538

[13] T. Kokubo, H. Kushitani, S. Sakka, T. Kitsugi, T. Yamamuro, Solutions able to reproduce in vivo surface-structure changes in bioactive glassceramic A-W, J. Biomed. Mater. Res., 24 (1990), pp. 721-734 DOI: 10.1002/jbm.820240607

[14] Y. FAN, X. LU, A study of apatite formation on natural nano-hydroxyapatite/chitosan composite in simulated body fluid, Front. Mater. Sci. China 2008, 2(1): 1-94 DOI 10.1007/s11706-008-0016-6 